\title{
İlkokul Türkçe Ders Kitaplarındaki Metinlerde Meslek Analizi
}

\author{
DOI: 10.26466/opus.688008
}

*

\begin{abstract}
Bahar Aydın *
* Öğr. Gör. Dr., Muğla Sıtkı Koçman Üniversitesi, Rektörlük Türk Dili Bölümü, Muğla/Türkiye E-Posta: baharaydin@mu.edu.tr

ORCID: $\underline{0000-0002-4309-8226}$

\section{Öz}

Çocukların eğitiminde önemli yere sahip olan kitaplar onların hayata hazırlanmasına da yardımcı olur. İlk öğrenim seviyesindeki kitaplarda yer alan kahramanların özellikleri ve bu kahramanların yaptıkları meslekler çocukların ileride mesleklere karşı tutumların belirlemede etkili olmaktadır. Öğrenmelerin temellendiği ve desteklendiği dönemlerde çocuklarla buluşan kitaplar, onların örnek alabileceği modeller yaratarak toplumsallaşma sürecine katkı sağlamaktadır. Bu yüzden kahramanların üstlendikleri meslekler ve bu mesleklerin cinsiyetlere göre nasıl dă̆̆ldı̆̆ı son derece önemlidir. Araştırmanın amacı ilkokul Türkçe ders kitaplarındaki metinlerde yer verilen meslekler ve cinsiyete göre meslek dağılımının nasıl olduğunu incelemektir. Bu araştırma nitel bir çalışmadır. Çalışmanın örneklemini 2018-2019 ĕ̆itim öğretim yılı için Talim Terbiye Kurulu Başkanlığı tarafindan önerilen MEB Yayınları ve özel yayınevlerinden oluşan 1-4. Sinıf düzeyindeki toplam 4 Türkçe ders kitabı oluşturmaktadır. Ders kitaplarındaki tema metinleri ve bunlara ait görseller incelenmiştir. İçerik analizi ile ortaya çıkarılacak bulgular söylem analizi yöntemiyle değerlendirilmiştir. Metinlerde yer alan resimlerden de bulguları elde etmede yararlanılmıştır.

Anahtar Kelimeler: Türkçe ders kitapları, meslek adları, toplumsal cinsiyet, çocuk edebiyatı. 
ISSN: 2528-9527

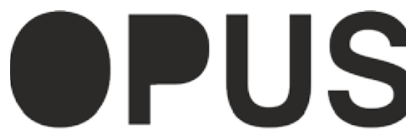

E-ISSN : 2528-9535

Yıl Year: 11

Cilt Volume: 17

Sayı Issue:34

Uluslararası Toplum Araştırmaları Dergisi

International Journal of Society Researches

Şubat February 2021

Makalenin Gelis Tarihi Received Date. 11/02/2020

Makalenin Kabul Tarihi Accepted Date. 28/01/2021

\title{
The Occupational Analyses in Turkish Course Books
}

\begin{abstract}
Books have an important place in the education of children. Books prepare children for life. Especially the characteristics and occupations of the heroes in the books at primary level are effective in determining the attitudes of children towards the professions in the future. For this reason, the occupations undertaken by the heroes and how these occupations are divided by gender are extremely important.

The aim of the study is to examine the distribution of occupations according to the professions and gender in the textbooks of primary school Turkish course books. This research is a qualitative study. The sample of the study consists of four course books taught in primary school in the 2018-2019 academic year. In research texts in the textbooks and pictures of these texts will be examined.
\end{abstract}

Keywords: Turkish Course book, profession name, social gender, children's literature 


\section{Giriş}

Edebiyatın bireylerin özellikle de çocukların eğitiminde önemli bir etkiye sahip olduğu yadsınamaz bir gerçektir. Edebi eserlerin çocukları yaşama hazırlaması onlara yaşamla ilgili uyarıcıları çocuğa ulaştırmayla olur. Türkçe öğretiminde önemli yeri olan yazınsal metinler; dilin sanatsal, düşünsel, sezgisel, sistematik birçok boyutuyla kullanıldığı metinlerdir. Çocuk edebiyatı ürünleri hangi tür olursa olsun, ele aldıkları konular, kullanılan anlatım teknikleri ve yer verilen kişi kadrosu bakımından çocukların dünyasını olumlu yönde geliştirmeye, onlara birtakım değer ve davranışlar kazandırmaya yöneliktir. Kitapların çocukların kişilik gelişimine de katkısı büyüktür. İnsan kişiliğinin okul döneminde, özdeşim kurma, kahramanların fiziksel ve ruhsal özelliklerinden, onların davranış ve eylemlerinden etkilenme en etkili ve hızlı öğrenme yoludur.

Teknolojik gelişmenin bu kadar yoğun olduğu ve eğitim sistemine de dâhil olduğu günümüzde ders kitapları en önemli ders materyalidir. Eğitim yönünden bakıldığında ders kitaplarının bu kadar yaygın kullanılmasında hem kullanım kolaylığının olması hem her öğrencinin ulaşabildiği kaynaklar olmaları etkilidir. Bu durum ders kitaplarının sahip olması gereken niteliklerin önemini daha da arttırmaktadır. Model alma aileden, çevreden ve kitaplardan gelir. Eğitim ortamlarında çocuğa sunulan toplumsal mesajlar bu bakımdan önem kazanmaktadır. Kitaplar çocukları etkiler ve şekillendirir. Okul öncesi dönemde masallar, hikâyeler, resimli kitaplar, okul dönemlerinde ders kitapları ve diğer kaynak kitaplar çocukların cinsiyet kalıp yargı ve rollerini öğrenmede önemli unsurlardır. Bu bakımdan erken çocukluk döneminde okullarda sunulan kitaplarda verilen mesajlar ve işlenen temalar oldukça önemlidir.

Dökmen (2004) sosyal öğrenme kuramını ödül ceza yöntemiyle öğrenme olarak özetlenebilen edimsel koşullanma ve davranışların model alındığı gözlenen figürlerin söz konusu olduğu taklit süreçlerinin önem kazandığ kuram olarak tanımlar. Gözleme dayalı öğrenme olarak da tanımlanan sosyal öğrenme kuramına göre birey, sosyal çevresinde yer alan davranışları gözlemleyerek öğrenir. Çocuklar için aileleri, arkadaşları, öğretmenleri, kitle iletişim araçları ve kitaplar model olmaktadır. Çocuklarda toplumsal cinsiyet 
farkındalığı, genellikle 7 yaş civarında oluşmaya başlamakta, içinde bulunduğu kültüre ait toplumsal normları ve davranış biçimlerini anlayabilme kabiliyeti gelişmektedir.

Çocukların toplumsal cinsiyete yönelik düşüncelerinin şekil alması için bu rollerinin nasıl sunulduğu önem taşımaktadır. Türkçe ders kitaplarındaki metinler çocukların eğitiminde önemli bir etkiye sahiptir. Erken dönemde uygun kitaplar ile karşılaşan çocuğun dil, zihin ve duygu gelişiminin yanı sıra, sosyal gelişimi de olumlu yönden etkilenmektedir. Ele aldıkları konular, kullanılan anlatım teknikleri ve yer verilen kişi kadrosu yönünden çocukların dünyasını olumlu yönde geliştirmeye, onlara kültürel, sosyal ve bilimsel değerleri aktarmaya ve davranış kazandırmaya yöneliktir. Çocuklar kitaplar ile okuduğu ya da dinlediği metinlerdeki kahramanlar vasıtasılyla insanların başından geçebilecek olayları, yaşanabilecek sorunları tanır, insan ve toplum yaşamını belirleyen değerleri anlar. Türkçe ders kitaplarındaki metinler, gerçek hayattan kesitler sunmanın yanında ideal toplumsal rollerin nasıl olması gerektiğini de aktarmalıdır. Çocuklar kahramanlar ile özdeşim kurmaya, kahraman gibi duymaya, düşünmeye, hareket etmeye istekli olurlar. Cinsiyet rollerinin çocuklara öğretilmesinde aile, sosyal çevre, reklam, televizyon, gazete gibi kitle iletişim araçları ile öyküleri, masallar ve ders kitapları oldukça etkilidir.

Ders kitaplarının gerek görsel gerek içerik gerekse bireye model olması gibi birçok yönü bireyin gelişiminde büyük etkilere sahiptir. Günay ve Gürşişmek (2005) çocuk kitaplarındaki cinsiyet rollerinin işlenişiyle ilgili araştırmalarında toplumsal değer yargılarının, kadınların ve erkeklerin yaptıkları mesleklerin belirlenmesinde önemli rol oynadığını saptamıştır. Resimli çocuk kitaplarında kadın ve erkek kahramanlara yüklenen meslek özellikleri çocukların ileriki yaşlarında mesleklere karşı oluşabilecek ön yargılarını belirlemektedir.

Dünyada olduğu gibi, ülkemizde de kadınların pek çok alanda erkeklere göre dezavantajlı bir konumda olduğu bilinmektedir. Cinsiyet ve toplumsal cinsiyet kavramları anlam bakımından birbirinden ayrilmaktadır. Toplumdan topluma farklılık göstermeyen cinsiyet kavramından farklı olarak, toplumsal cinsiyet kavramı, zamana, kültüre, hatta aileden aileye bile değişiklik gösterebilir (Çelik, 2008). Cinsiyet, fiziksel ve biyolojik özelliklerle ile ilgili bilgileri içerdiği için evrensel olarak farklılık göstermezken toplumsal cinsiyetin 
tanımlanmasında etkileşimler ve kültürel ögelerle çizilen değişkenler etkilidir. Dökmen (2004) toplumsal cinsiyet kavramını; toplumun görüşü, algısı, düşüncesi ve davranış biçimi olarak ifade eder. Kültürel olarak kadına ve erkeğe uygun görülen, toplum tarafindan kalıp yargılara dönüştürülen kişilik özellikleri ve davranışları içerir. Aydilek Çiftçi (2011) ise cinsiyeti biyolojik farklılıklardan ziyade, toplumun kadın ve erkeğe yüklediği roller, onlardan beklediği davranış kalıpları olarak tanımlanmaktadır. Kısacası toplumsal cinsiyet biyolojik bir farklılık değil, erkek ve kadını toplumun nasıl algıladığı, nasıl davranmasını beklediğiyle ilgili bir kavramdır. Biyolojik cinsiyet farkı dışında, psikolojik, toplumsal ve kültürel farklılıklarla beslenir.

Cinsiyete, toplumsal cinsiyet algısı bakımından farklı manalar yüklenmekle birlikte toplumun yüklediği cinsiyet kalıpları ve ayrımlarına göre meslekler de şekillenmektedir. Kadın ve erkeğin toplumdaki görevleri, sorumlulukları, hakları, maddi ve manevi her türden üretimdeki konumları, kişilik özellikleri sayılabilen her unsur vb. toplumsal cinsiyete göre şekillendirilir (Helvacıoğlu, 1996). Cinsiyet önyargıları iki cinsin birbirinden hangi bakımdan ayrıldıklarına, nasıl davranmaları gerektiğine ilişkin inançları ifade eder.

Eğitim eşitliğini engelleyen toplumsal faktörlerden biri de cinsiyet ayrımıdir. Toplumsal cinsiyet rollerinin aktarılmasında ve devam ettirilmesinde okulların önemli rolü vardır. Farkında olmadan işleyen bu süreçte ders kitaplarının da önemli bir rolü vardır. Okullarda hem öğretmenler hem ders kitapları aracılığıyla geleneksel cinsiyet rolleri sunulur ve hissettirilir. Küçük yaşlardan itibaren çocuk eğitiminde bu kadar önem taşıyan kitapların özenle hazırlanması gerekir. Ders kitaplarına cinsiyetin yansıması konusunda pek çok araştırma yapılmıştır (Esen Severge, 1998; Kırbaşıŏlu Kılıç ve Eyüp, 2011; Kitiş Çınar, 2013; Gümüşoğlu, 2008; Yorganc1, 2008; Demirel, 2010; Özkan, 2013; Köseler, 2009). Bu çalışmalardan elde edilen bulgular birbirleriyle yakın ilişkili olduğu görülmüştür. Kadınların pasif olduğu, ev içinde bulunduğu; erkeklerin ise ev dışı alanlarda bağımsız, baskın bireyler olarak gösterildiği görülmüştür. Çocuklar için hazırlanan eserlerin kişi kadroları bu bakımdan son derece önemlidir. Çocuklar, okudukları kitap, film ya da oyunların kahramanlarıyla özdeşim kurarlar. Bu bakımdan Yavuzer (2005) de, çocuk kitaplarının hazırlanmasında çocuğun kişiliğinin ve gelişim özelliğinin dikkate alınması gerektiğini vurgulamıştır. Çocukların toplumsal değerlerinin şekil- 
lenmesinde etkili olan aile, sosyal çevre ve eğitimde kullanılan kitaplar, çocukların meslek seçimlerinde ve mesleklere ilişkin toplumsal cinsiyet algılarının oluşmasında da temel oluşturmaktadır.

Cinsiyete, toplumsal cinsiyet algısı bakımından yüklenen farklı anlamlarla birlikte mesleklerin şekillenmesinde toplumun oluşturduğu cinsiyet kalıpları ve ayrımları da etkili olmaktadır. Çocukların kitaplar ve kitap görselleri yoluyla kahramanların yaptıkları meslekleri ve özelliklerini, bu meslekleri yapan kahramanların cinsiyetlerini öğrendikleri kaçınılmazdır. Bu bakımdan, kitaplarda anlamı oluşturan ve çocuğun hayal dünyasını geliştiren önemli unsurlardan biri de görsellerdir. Toplumsal cinsiyet kalıp yargıları görseller aracılığıyla da fark etmeden korunan, yeniden üretilen yapılar olarak karşımıza çımaktadır. Batur'a (2010) göre görseller çocukların kendi düşünce dünyalarını yaratmalarına katkıda bulunur. Bu yüzden, ders kitaplarında yer verilen görsellere metinler kadar önem verilmeli, görseller özenle hazırlanmalıdır. Kitaplarda yanlı resimlerin kullanılması çocukların hayatlarındaki olasılıkların çeşitlenmesi ve gelişmesi de engellenmektedir. Eğitim kurumlarında kullanılan ders kitaplarının toplumsal cinsiyet rolleri bakımından incelenmesi önemlidir. Bu kitaplarda yer alan resimler ve anlatımlar duyarlı bir bakış açısıyla oluşturulmalıdır. Bu çalışmada ders kitaplarında yer verilen meslekler ve belki de bir çoğumuzun farkına bile varmadığı bu mesleklerin cinsiyete göre dağılımı incelenecektir.

\section{Amaç ve Yöntem}

Araştırmanın amacını yayınlanan ilkokul Türkçe ders kitaplarındaki metinlerde yer verilen meslekler ve cinsiyete göre meslek dağılımının nasıl olduğunu incelemek oluşturmaktadır. Bu amaca ulaşmak için aşağıdaki sorulara yanit aranacaktır:

1. İlkokul Türkçe ders kitaplarındaki meslek kavramları hangileridir?

2. Mesleklerin cinsiyete göre dağılımı nasıl olmuştur?

Genel tarama desenine göre yapılan bu çalışma betimsel bir özellik taşımaktadır. Çalışmada doküman incelemesi yoluyla toplanan verilerin analizi içerik çözümlemesi yoluyla yapılmıştır. Buna göre 2018-2019 Eğitim-Öğretim yılında ilkokullarda okutulan MEB Yayınları ve özel yayınevlerinden oluşan 4 Türkçe ders kitabındaki tüm metinlerde geçen meslek adları ortaya koyulmuştur. Diğer aşamada her sınıf düzeyindeki kitapların içerdiği mesleklerin 
cinsiyetlere göre dağılımı da yorumlanmıştır. Türkçe ders kitaplarında yer alan metinlerde meslek adları doğruya alınmıştır. Daha sonra elde edilen meslekler söylem analizi çerçevesinde değerlendirilip bu mesleklerin ilişkilendirildikleri cinsiyet özellikleri çözümlenmiştir. Bu çözümlemede metinlerin içinde yer alan resimlerden de yararlanılmıştır.

Araştırmanın örneklemi 2018-2019 eğitim öğretim yllında kullanılan ilkokul Türkçe ders kitapları metinleri görsellerinden oluşmaktadır. İncelenen ders kitapları şunlardır:

1. İlkokul Türkçe ders kitabı 1. Sınıf (Civelek, Gündüz, Karafilik, 2018)

2. İlkokul Türkçe ders kitabı 2. Sınıf (Ataş̧̧i, 2018, Koza Yayın)

3. İlkokul Türkçe ders kitabı 3. Sınıf (Çeltik, 2018, Sdr Dikey Yayıncılık)

4. İlkokul Türkçe ders kitabı 4. Sınıf (Kaftan Ayan, Arslan, Kul ve Yılmaz, 2018, MEB yayınları)

\section{Bulgular}

Araştırmanın bulguları, sınıf düzeyine göre, aşağıdaki biçimiyle sunulmuştur.

Tablo 1. 1. sını MEB yayınevi meslek adlan ve cinsiyet dağılımları

\begin{tabular}{llll}
\hline Meslek & Cinsiyet & Meslek & Cinsiyet \\
\hline Öğretmen & Kadın & Astronot & - \\
\hline Doktor & - & Şoför & - \\
\hline Kayıçı & - & Asker & Erkek \\
\hline Saraç & - & Mucit & Erkek \\
\hline Doğramacı & - & Bilgin & Erkek \\
\hline Demirci & - & Bilim insanı & Erkek \\
\hline Memur & - & Hava Subayı & - \\
\hline
\end{tabular}

MEB yayınevinden çıkan 1. sınıf Türkçe ders kitabındaki metinler mesleklere yer verilmesi yönünden incelendiğinde kitap metinlerinde14 farklı meslek adı bulunmaktadır. Bu meslek kavramlarından, öğretmen en fazla sıklığa sahip kavram (4) olarak bulunmuştur. Bir metinde öğretmen kavramı kadın olarak resmedilmiştir. Bunun dışında öğretmen mesleğinin kullanıldığı diğer metinlerde öğretmenin cinsiyeti ile ilgili herhangi bir açılamaya yer verilmemiştir.

Kitapta yer alan mesleklerden asker, metinde geçen kahramanın dedesi olarak açıklanmıştır. Mucit, bilgin ve bilim insanı meslekleri de erkek kimliği ile karşımıza çıkmaktadır. "Başıma İcat Çıkarma” adlı metinde mucit olarak 
Matrakçı Nasuh, bilgin olarak da Hezarfen Ahmet Çelebi örnek gösterilmiştir. "İbni Sina" adlı metinde ise bilim insanı olarak İbni Sina yer almıştır. 1. Sınıf Türkçe ders kitabında yer alan diğer meslek gruplarının cinsiyetleri ile ilgili metinlerde herhangi bir açıklama ya da resim bulunmamaktadır.

Tablo 2. 2. sınf Koza yayınları meslek adları ve cinsiyet dağılımlar

\begin{tabular}{llll}
\hline Meslek & Cinsiyet & Meslek & Cinsiyet \\
\hline Kaptan & Erkek & Bakkal & - \\
\hline Asker & Erkek & Öğretmen & Erkek \\
\hline Şair & - & Dişçi & Erkek \\
\hline Yazar & Erkek & Futbolcu & Erkek \\
\hline Yer gösterici & Erkek & Antrenör & Erkek \\
\hline Er & Erkek & Kaleci & Erkek \\
\hline Hizmetçi & - & Sporcu & Erkek \\
\hline Çiftçi & Erkek & & \\
\hline
\end{tabular}

Koza yayınlarından çıkan 2. Sınıf Türkçe ders kitabında ise 15 farklı meslek kavramı bulunmaktadır. Bu kavramlardan 12 tanesi erkek kahraman tarafından yapılan meslekler olarak karşımıza çıkarken geri kalan 3 meslek için herhangi bir cinsiyet açık olarak belirtilmemiştir. 2. Sınıf Türkçe ders kitabındaki metinlerde kadın kahramanların temsil ettiği mesleklere ise hiç yer verilmemiştir. Güney (2016) de 2015-2016 eğitim öğretim yllında okutulan ortaokul Türkçe ders kitapları üzerine yaptığı çalışmasında erkeklerin kadınlara oranla mesleklerde daha fazla gösterildiğini belirtmiştir.

"Arkadaşım Papi" metninde "Benim babam bir kaptan" ifadesinden kaptanlık mesleğine erkek kimlik verilmiş olduğunu görmekteyiz. "Efe Tiyatroya Gidiyor" metninde tiyatro salonunda yer gösterici olarak çalışan karakter ile "Şehit Mehmet Kamil" metninde Mehmet Kamil' in pencereden gördüğü Fransız askerleri de metinlerdeki resimlerde erkek olarak resmedilmiştir.

"Çanakkale'den Sonra" metninde yazar olarak Ömer Seyfettin belirtilmiştir. "Asker Ağlamaz Arkadaş" serbest okuma metninde er olarak, "Yerli Malları Tutum Haftası" metninde öğretmen olarak ve "Çiftçiyle Oğulları" metninde yaşli çiftçi olarak erkek kahramanlar resmedilmiştir.

"Selim ve Pelin" başlıklı karikatür şeklinde düzenlenen metinde dişçi yine erkek olarak çizilmiştir. "Gerçek Bir Meslek" metninde futbolcu, kaleci ve antrenör olarak da erkek karakterlerin resimlendiğini görmekteyiz. 
"Bakkal", "şair" ve "hizmetçi" mesleklerini temsil eden cinsiyetler için ise kitap metinlerinde ve metin resimlerinde herhangi bir açıklayıcı ifadeye yer verilmemiş ve meslekler sadece isim olarak metinlerde yer almıştır.

Tablo 3. 3. sını Sdr Dikey yayıncılık meslek adları ve cinsiyet dağılımları

\begin{tabular}{llll}
\hline Meslek & Cinsiyet & Meslek & Cinsiyet \\
\hline Dalgı̧ & - & Muhtar & Erkek \\
\hline Manav & - & Doktor & Kadın \\
\hline Astronot & Erkek & Kaptan & Erkek \\
\hline Kadı & Erkek & Kayıkçı & - \\
\hline Yemiş̧̧ & Erkek & Şair & Erkek \\
\hline Kumaşçı & Erkek & Okul müdürü & - \\
\hline Öğretmen & - & & \\
\hline
\end{tabular}

Sdr Dikey yayınclık 3. Sınıf Türkçe ders kitabında 13 farklı meslek adına yer verilmiştir. Bu mesleklerin cinsiyet dağılıma baktığımızda 7 meslek erkek, 1 meslek kadın tarafından icra edilmektedir. 5 meslek ile ilgili ise herhangi bir cinsiyet bilgisi yer almamaktadır.

"Uzaya yolculuk" metninde astronot olarak hikâyenin erkek kahramanı yer almıştır. "Kim Haklı" okuma metninde ise kadılık görevini Nasreddin Hoca yapmaktadır. Serbest okuma parçası olan “Orhan'ın Düdüğü"nde yemişçi ve kumaşçı meslekleri için metinlerde bir açıklamaya yer verilmezken metin resimlerine baktığımızda mesleklerin erkek kahramanlar tarafından yapıldığı resmedilmiştir. "Bayrak Hasreti" metninde ise köy muhtarı, metin kahramanımız Ali'nin babasıdır.

3. Sınıf Türkçe ders kitabında kadınlar tarafından yapılan tek meslek "Geçmiş Olsun Ecenur" metnindeki Ecenur'u muayene eden doktordur. Yine metin içinde doktorun cinsiyeti ile ilgili açık bir bilgi bulunmazken doktorun kadın olduğunu metindeki resimden anlamaktayız. "Beyaz Kuş" metninde yer alan kaptan ve şair mesleklerini yapan da metnin erkek kahramanı Berk'tir.

"Dalgıç", "manav", "öğretmen", "kayıkçı" ve "okul müdürü" meslekleri için ise metinlerde ve metin resimlerinde cinsiyeti belirten herhengi bir açıklama bulunmamaktadır. 
Tablo 4. 4. sınıf MEB yayınevi meslek adları ve cinsiyet dağılımları

\begin{tabular}{llllll}
\hline Meslek & Cinsiyet & Meslek & Cinsiyet & Meslek & Cinsiyet \\
\hline Şair & Erkek & Mucit & Kadın/erkek & Zenne & - \\
\hline Öğretmen & Erkek & Bilim insanı & Kadın & Aşçıbaşı & - \\
\hline Asker & - & Bilim adamı & Erkek & Tüccar & - \\
\hline Komutan & Erkek & Mühendis & Erkek & Güreşçi & Erkek \\
\hline Pilot & Erkek & Yazar & Erkek & Doktor & - \\
\hline Makinist & - & Rehber & - & Yüzücü & - \\
\hline Ciğerci & Erkek & Motorcu & - & Heykeltıraş & - \\
\hline Tamirci & Erkek & Manici & - & Gitarist & - \\
\hline Sihirbaz & Erkek & Paçacı & - & Sedef ustası & - \\
\hline & & Davulcu & - & Cam ustası & - \\
\hline & Telkâri ustası & Kadın & Ebru ustası & - \\
\hline
\end{tabular}

Diğer sınıf düzeylerinden farklı olarak MEB yayınevi 4 . Sınıf Türkçe ders kitabında bulunan metinlerde toplam 31 mesleğe yer verilmiştir. En çok meslek adı bu sınıf düzeyinde tespit edilmiştir. 32 meslekten 11 tanesinin cinsiyeti erkek 3 tanesinin kadındır. 17 mesleğin cinsiyeti hakkında ise herhangi açıklayıcı bir bilgi bulunmamaktadır.

Serbest okuma metni olan "Şermin 1914"te şair ve öğretmen olarak Tevfik Fikret'e yer verilmiştir. Yine serbest okuma metni olan "Vecihi Hürkuş"ta anlatıcının eniştesi komutan, anlatıcı olan Vecihi de pilot ve öğretmendir.

"Güneşi Bile Tamir Eden Adam" metninde Muammer Bey, adanın ciğercisi, kardeşi Kadir Bey de tamircisidir. Ve kahramanlarımızdan Melisa, Kadir Bey'in bir sihirbaz olduğundan bahseder.

Bilim ve teknoloji temasında bulunan "Küçük Mucitler" metninde yer alan resimde mucit olarak hem kız hem erkek çocuklara yer verilmiştir. Metin içinde meslekleri temsil eden cinsiyetlerle ilgili herhangi bir açıklayıcı ifade bulunmamaktadır. "İcat Nasıl Yapılır?" metninde bilim insanı örneği olarak Canan Dağdeviren bulunmaktadır. "Robotların Efendisi: Cezeri" metninde Cezeri başmühendistir. "Kaybolan Cennet" te ise yazar olarak Salih Acar'a yer verilmiştir.

“ilk Güreşçimiz Koca Yusuf ve Başarısının Sırrı” metninde ünlü Rus güreşçi Hakimşmit vardır. "Asker", "machinist", "doctor", "rehber", "motorcu", "manici", "paçacı", “davulcu", “zenne", "aş̧̧başı", "tüccar", "yüzücü", “heykeltraş", "gitarist", "sedef ustası", "cam ustası" ve "ebru ustası" ile ilgili herhangi bir cinsiyet açıklaması metinlerde ve metin görsellerinde bulunmamaktadır. 


\section{Tartışma ve Sonuç}

MEB yayınları ve özel yayınevlerine ait ilkokul Türkçe ders kitapları tema içindeki metinlerde yer alan meslek kavramları ve bu mesleklerin cinsiyet rollerine göre dağılımı incelenmiş ve şu sonuçlara ulaşılmıştır:

İlkokul çocukları için en çok okunan kitaplardan biri olan ders kitaplarında toplumsal cinsiyet rollerinin meslekler açısından dağılımının çözümlemesi yapılmış ve toplumsal cinsiyet rollerinin mesleki dağılımı arasında farklılıklar bulunmuştur. Ders kitapları kadın ve erkeklere uygun görülen meslekler yönünden incelendiği zaman dört sınıf düzeyindeki kitaplarda da kadın ve erkeklerin mesleklerde temsil edilme oranları arasında büyük fark bulunmaktadır. Ders kitaplarında mesleklerin temsil edilme oranları açısından erkeklerin lehine bir durumu ortaya çıkartmaktadır. İncelenen ders kitaplarındaki görsellerde erkek görsel sayısının kadın/kız çocuk görsel sayısından fazla olduğu tespit edilmiştir. Kitaplarda kadınların meslek dağılımının oldukça sınırlı olduğu, buna karşılık erkeklerin meslek alanlarının kadınlara oranla daha geniş olduğu belirlenmiştir. Erkeklerin meslek alanlarının metinlerde temsil edilme oranı kadınlarınkinden çok daha fazladır. Çocuklara bu şekilde aktarılan toplumsal cinsiyet eşitsizliğine dair bu örnekler onların alg1 ve tutumların etkilemektedir.

İncelenen kitaplarında kadınların az sayıda ve belli meslek gruplarında temsil edildiği tespit edilmiştir. Kadınların sadece belirli mesleklerde var olması toplumsal cinsiyet önyargısını da ortaya koymaktadır. Ders kitaplarında, toplumsal cinsiyet önyargılarının bu yüzyılda da hala sürdürüldüğü görülmektedir. Meslekler konusunda da toplumsal cinsiyet önyargıları kendisini göstermektedir. Kitaplarda yer alan metinlerde ve metin resimlerinde, kadınlara oranla ağır basan erkekler, meslek dağılımında çok daha fazla bir yer tutmaktadır. Kadın kahramanların metinlerde sadece öğretmen, doktor, bilim insanı, mucit ve telkâri ustası meslekleriyle temsil edilmesi, mesleklere ve kadın erkek meslek dağılımına yönelik önyargıların da tam olarak ortadan kalkmadığını bize göstermektedir. Toplumsal cinsiyete bakış açısını etkileyen araçlardan biri olan kitapların etkisi düşünüldüğünde, bu önyargının çocukların en önemli gelişim dönemlerinde oluşturulması onların ilerleyen yaşlarında yer alacakları toplumun içinde kadın erkek eşitliği konusunda bir dezavantaj oluşturacağı açıktır. 
Erken çocukluk dönemine seslenen Türkçe ders kitaplarda erkek ve kad1nın mesleki hayat içinde benzer sorumluluk ve görev aldığı metinlere kitaplarda da fazla yer verilmelidir. Kitaplarda öne sadece erkek kahramanlar ve onların meslekleri çıkarılmamalıdır. Kadın kahramanların da erkekler kadar çeşitli mesleklerde görev aldıkları ve başarılı oldukları gösterilmelidir.

İncelenen ders kitaplarında erkeklerin kadınlara oranla resmedilme oranının fark edilir düzeyde daha yüksek olduğu görülmüştür. Kitaplarda yer alan görsellerde kadın-erkek ve kız-oğlan figürlerinin temsil ettikleri roller cinsiyetçi tutumlar içerisinde gösterilmemelidir. Çağdaş bir toplum olmanın ön koşullarından olan kadın ve erkek eşitliğinin ders kitaplarında daha özenli işlenmesi önem arz etmektedir.

Ders kitaplarının metinler ve görseller açısından incelenmesi sonucunda kitaplarda toplumsal cinsiyet kalıp yargılarının zamanla azalmasına rağmen hala yaygın olduğu görülmüştür. Ders kitaplarının hazırlanmasında toplumsal cinsiyet eşitliği konusunda daha hassas davranılmalı, metinlerde kadın karakterler daha geniş mesleklerde yer verilmelidir.

Çocukların meslekler konusunda kalıp yargılarını düzenleme için eğitici ve bilgilendirici etkinlikler uygulanmalıdır.

Ders kitaplarında ayrımcılık içeren cinsiyetçi yaklaşımların olmamasına dikkat edilmelidir. Kitap metinleri ve metin görselleri kadın ve erkek arasında dengeli bir dağılım olacak şekilde daha büyük titizlikle hazırlanmalıdir.

Okul duvarlarınızda, sınıflarda asılı resimlerde erkek bilim insanları ve sanatçıların yanı sıra ünlü kadın bilim insanları ve sanatçıların resimleri ve başarıları paylaşılmalıdır.

Sınıflardaki iş bölümü cinsiyet eşitliği gözetilerek yapılmalıdır.

Meslek tanıtımları her yaş düzeyinde yapılmalıdır ve mesleklerin tanıtıldığı etkinliklerde toplumsal cinsiyet konusunda farkındalık yaratmak ön planda olmalıdır.

Öğretmenler, toplumsal cinsiyet ve cinsiyetçilik konusunda bilinçlendirilmelidir. Cinsel kalıplaşmaları ortadan kaldıracak eleştirel bilinç kazanmalıdirlar.

Çocuklar toplumsal cinsiyet rollerini, kalıp yargılarını ailelerinde öğrenmeye başlarlar. Ailelerin de cinsiyetçilik konusunda bilinçlenmeleri sağlanmalidir. 


\title{
EXTENDED ABSTRACT
}

\section{The Occupational Analyses in Turkish Course Books}

\author{
Bahar Aydin \\ Muğla Sttkı Koçman University
}

It is an undeniable fact that literature has an important impact on the education of individuals, especially children. Literary products bring the stimuli of life to the child and prepare them for life. Regardless of the genre, children's literature products are aimed at positively improving the world of children in terms of their subjects, narrative techniques and staff, and imparting some values and behaviors to them. Books are also of great importance in personality development. Human personality is the most effective and fast way to learn during school, identification, being influenced by the physical and mental characteristics of the heroes, their behavior and actions.

Even today, where technological development is so intense and included in the education system, textbooks remain the most important course material. In terms of education, both the ease of use and the resources that each student can access cause the use of textbooks so widely. This situation increases the importance of the qualifications that textbooks should have.

Texts in Turkish textbooks have a significant impact on the education of children. The subjects they deal with are aimed at developing the world of children positively in terms of narrative techniques and personal staff, and conveying cultural, social and scientific values and giving them behavior. The texts in the Turkish textbooks should provide real life cross-sections as well as how the ideal social role should be.

The school has an important function in maintaining and transmitting gender roles. In schools, traditional gender roles are presented and felt through both teachers and textbooks. Books have an important place in children's education from an early age. Books of such importance in the child's life should be prepared with care. Personnel cadres of works prepared for children are extremely important in this regard.

It is inevitable that children learn the professions and characteristics of the heroes in the books, and the genders of the heroes who do these professions 
through books and visuals. One of the important elements that make sense in books and develop the child's imagination is visuals in this respect.

The aim of the study is to examine the distribution of occupations by gender and occupations in the textbooks in the Turkish textbooks published in the 21st century. To achieve this goal, the following questions will be sought: "Are primary school Turkish textbooks equipped with rich vocational concepts?" and "What was the distribution of occupations by gender?"

There are 14 different occupational names in the first year Turkish textbook. Among these concepts, the teacher has the most frequency (4). In a text, the concept of teacher is depicted as a woman. Apart from this, in the other texts in which the teacher profession is used, there is no explanation about the gender of the teacher. In the second year Turkish textbook, there are 15 vocational concepts. While 12 of these concepts appeared as male heroes, no gender was explicitly stated for the remaining 3 occupations. In the 3rd grade Turkish textbook, 13 different occupations are included. When we look at the gender distribution of these occupations, 7 occupations are performed by men and 1 occupation by women. There is no gender information about 5 occupations. A total of 32 professions are included in the texts in the 4 th grade Turkish textbook. Most occupational names were determined at this class level. Of the 32 occupations, 11 were male and 3 were female.

In the textbooks, one of the most widely read books for primary school children, the distribution of gender roles in terms of occupations was analyzed and differences were found between the professional distribution of gender roles. When the textbooks are examined in terms of occupations deemed appropriate for male and female individuals, there is a big difference between the representation rates of male and female professions in the four grade level books. In the textbooks examined, it was determined that the occupational fields of women were quite limited, whereas the occupational fields of men were wider than that of women. In the books examined, it was found that women were represented in a small number and in certain occupational groups. The existence of women only in certain occupations reveals gender bias. Gender prejudices also manifest themselves in occupations. In the texts and text paintings in the books, men, which outweigh women, occupy a more weighted place in the occupation distribution. Only male heroes and their professions should not be put forward in the books. It should be 
shown that female heroes are employed and successful in various professions as well as men. Teachers should be made aware of gender and gender.

\section{Kaynakça / References}

Aydilek Çiftçi, M. (2011). Öğretmenlerin ve farklı sosyoekonomik düzeye sahip anne-babalarnn cinsiyet rolleri algisının 60-72 ay arası çocukların oyuncak tercihleri ve akran etkileşimleri ile ilişkisinin incelenmesi. Yayımlanmamış Yüksek Lisans Tezi. Çukurova Üniversitesi Sosyal Bilimler Enstitüsü, Adana.

Batur, Z. (2010). Son çeyrek yüzyılda kadının değişen sosyal statüsü ve imaji: İlköğretim ikinci kademe anadili ders kitaplarında metin ve görsel ögelerin incelenmesi. Uluslararası Sosyal Araştırmalar Dergisi, 3(13), 33-43.

Çelik, Ö. (2008). Ataerkil sistem bağlamında toplumsal cinsiyet ve cinsiyet rollerinin belirlenmesi. Yayımlanmamış Yüksek Lisans Tezi, Gazi Üniversitesi Sosyal Bilimler Enstitüsü, Ankara.

Demirel, Ö. (2010). Sosyal bilgiler ders kitaplarnnda cinsiyet ayrumallğ̆. Yayımlanmamış yüksek lisans tezi. Dokuz Eylül Üniversitesi Eğitim Bilimleri Enstitüsü Ana Bilim Dalı Sosyal Bilgiler Öğretmenliği Programı, İzmir.

Dökmen, Y.Z. (2004). Toplumsal cinsiyet sosyal psikolojik açılamalar. Ankara: Sistem Yayincilik.

Esen Severge, Y. (1998). Ders kitaplarında cinsiyetçilik: Illköğretim ders kitapları üzerinde yapılmış bir içerik çözümlemesi. Yayımlanmamış yüksek lisans tezi. Ankara Üniversitesi Sosyal Bilimler Enstitüsü, Ankara.

Gümüşoğlu, F. (2008). Ders kitaplarında toplumsal cinsiyet. Toplum ve Demokrasi Dergisi, 2(4), 39-50.

Güney, N. (2016). 6. sınff Türkçe ders kitaplarında toplumsal cinsiyet incelemesi. Turkish Studies International Periodical for the Languages, Literature and History of Turkish or Turkic, 11(3), 229-1248.

Gürşimşek,I. ve Günay, V.D. (2005). Çocuk kitaplarında cinsiyet rollerinin işlenişinde kullanılan dilsel ve dildışı göstergelerin değerlendirilmesi. Dokuz Eylül Üniversitesi Buca Eğitim Fakültesi Dergisi, 18, 53-63

Helvacıoğlu, F. (1996). 1928'den 1994'e ders kitaplarnnda cinsiyetçilik. Yayımlanmamış Yüksek Lisans Tezi, İstanbul Üniversitesi Sosyal Bilimler Enstitüsü, İstanbul.

Kırbaşıoğlu Kılıç, L. ve Eyüp, B. (2011). İlköğretim Türkçe ders kitaplarında ortaya çlkan toplumsal cinsiyet roller üzerine bir inceleme. ODTÜ Sosyal Bilimler Enstitüsü Sosyal Bilimler Araştrmalan Dergisi, 2(3), 129-148. 
Kitiş Çınar, E (2013). Ortaokul Türkçe ders kitaplarında toplumsal cinsiyet. Yayımlanmamış Yüksek lisans tezi. T.C. Pamukkale Üniversitesi Eğitim Bilimleri Enstitüsü, Denizli.

Köseler, F. (2009). Okul öncesi öykü ve masal kitaplarnda toplumsal cinsiyet olgusu. Yayımlanmamış yüksek lisans tezi. Adnan Menderes Üniversitesi Sosyal Bilimler Enstitüsü, Denizli.

Özkan, R. (2013). İköğretim ders kitaplarında kadın figürü. The Journal of Academic Social Science Studies, 6(5), 617-631.

Yavuzer, H. (2016). Resimleriyle çocuk, resimleriyle çocuğu tanıma. İstanbul: Remzi Kitabevi.

Yorgancı, F. (2008). İköğretim ders kitaplarında toplumsal cinsiyet rollerinin inşası. Yayımlanmamış yüksek lisans tezi, Afyon Kocatepe Üniversitesi Sosyal Bilimler Enstitüsü, Afyon.

\section{Kaynakça Bilgisi / Citation Information}

Aydın, B. (2021). İlkokul Türkçe ders kitaplarındaki metinlerde meslek analizi. OPUS-Uluslararası Toplum Araştırmaları Dergisi, 17(34), 1047-1062. DOI: $10.26466 /$ opus.688008 